\title{
Men Who Stop Caring: The Exit of Men from Caring Occupations
}

\section{Kenn Warming'}

Special adviser, Equality Department, The Danish Institute for Human Rights, Denmark

\begin{abstract}
In recent years, initiatives have been taken to attract more men into caring occupations. However, there has been much less focus on retaining these new male workers. This article builds on qualitative interviews with I I Danish men who after working in the caring sector decided to leave for other occupations. A factor often presented as influential for the men's exit concerns the social working environment. In the interviews, the men discuss the pressure to assimilate to the existing and established female-dominated culture. They feel excluded and socially isolated. Several of them have been directly criticized or disqualified as not being "real" men by their female colleagues. As a result of a growing bureaucratic demand for control and registration of work procedures, several men feel that they do not have adequate resources and time to provide the level of care that is needed. They become disillusioned and frustrated and choose to seek employment elsewhere. Some men cannot come to terms with close physical contact and "smells," for example, changing diapers on infants or bathing old people. They cannot handle the thought of having their intentions misinterpreted, for example, when playing and being physical with children, and being potentially seen as sexually abhorrent. Finally, some men never intended to remain permanently in caring occupations. Their exit is driven by an ambition to pursue a career in another field or at what they view as a more challenging career level.
\end{abstract}

\section{KEY WORDS}

Caring occupations / discrimination / exit / gender minorities / men

"We need more men in the caring occupations!" In recent years, various initiatives have been undertaken in order to achieve this goal. The result has been an increase in the number of men being trained to enter the caring occupations. However, we seem to have forgotten that the path to a more gender-balanced care sector also depends on the capacity of this sector to retain these men. Retaining these male workers has proven to be even more difficult than attracting them. Men who enter care work become frustrated and leave the sector. This article focuses on the problem of retention of male labor in care work, providing a qualitative study of men's motivation for leaving the care sector.

\section{Introduction}

enmark has one of the world's most gender-segregated labor markets, where six out of ten people work in a gender-dominated occupation. Women often work in the public sector with people and with care, while men often work in the private sector with building trades and technical fields. The consequences are well known.

\footnotetext{
${ }^{1}$ Kenn Warming, The Danish Institute for Human Rights, Equality Department, Wilders Plads 8K, DK-1403 Copenhagen, Denmark. E-mail: kewa@humanrights.dk
} 
The labor market becomes inflexible, bottlenecks arise, and human resources and talents are not utilized, while the real freedom to choose one's work on the basis of personal preferences is restricted (Holt et al. 2006). Therefore, in recent decades, various measures and initiatives have been taken to reduce gender segregation on the labor market. Where it was formerly rare to see female doctors, lawyers, priests, and secondary school teachers, women now dominate these occupations (Sjørup 2011). Women have entered several fields requiring high-level university qualifications, while the building trades remain male-dominated (except for house painters, where about one-fourth are women) (Liversage 2009). Even though men and women are occupied in different sectors and areas, their unemployment rates are identical and made up $5.8 \%$ of the total labor force in May 2013. This rate has been relatively stable since the end of 2009 (Statistics Denmark 2013). A recently developed index that compares gender equality among European countries concludes that Denmark stands out positively by having a high degree of women participate on the labor market (European Institute for Gender Equality 2013).

In the care sector, where women predominate, we know that the shortage of labor will grow explosively in the coming decades (Kudahl 2009), and that there will be a need to recruit both male and female employees. Therefore, recent years have seen an increasing interest in attracting men into caring occupations. ${ }^{1}$

Surveying developments in gender distribution among students in several selected care-related educational programs over a ten-year period, it seems that more men are indeed entering the caring fields. Hence, between 2001 and 2010, the proportion of men training to be child and youth workers (the Danish term is poedagog) has increased from $18 \%$ to $25 \%$. In the same ten-year period, the proportion of men training as social and health care workers (lower and upper levels, called "social and health care helpers" and "social and health care assistants") has increased from $5 \%$ to $12 \%$, while the proportion of male nursing students has increased from $4 \%$ to $6 \%$ of all students (Uni C 2012).

However, it is not enough to attract men to these fields. The success of recruitment drives hinges on the ability to retain the male students/graduates in their jobs. Statistics show us that despite a decline in the proportion of male dropouts in two of the three educational programs, this article focus upon, a substantial part of male students who begin a caregiving educational program never complete their studies (see Table 1). ${ }^{2}$

Table I: Proportion of men among male students who drop out from three female-dominated educational programs (Uni C 20I2)

\begin{tabular}{lcc}
\hline Withdrawal from programs, men & 2001 (\%) & $2010(\%)$ \\
\hline Child and youth care & 24 & 28 \\
\hline Social and health care & 37 & 27 \\
\hline Nursing & 43 & 39 \\
\hline
\end{tabular}

Seen in light of the fact that an increased share of men in caring occupations touches on issues of both recruitment and retention, one would expect that both processes would be the object of research attention. In fact, retention has been relatively overlooked. There exist no studies that focus exclusively on men who leave the caring occupations for other work. This article seeks to address this gap. 
On the basis of interviews with 11 men who have chosen to leave the care sector for other work, this article elucidates the problem of "why men leave the caring occupations." The objective is to achieve a greater understanding of the barriers and exclusion mechanisms which cause men, who have entered care training or work, to leave the sector. The intention here is to foreground knowledge that is anchored in men's lived experience. In this way, we can help achieve a higher degree of retention, that is, a greater gender balance in the predominantly female-dominated caring occupations. It should be emphasized here that female workers may also exit the care sector. However, the intention here is not to compare men's and women's motivations for leaving care work. The focus is exclusively on men's experiences and motivations.

\section{What do we know about men who exit female-dominated occupations?}

Of the limited data on men who leave female-dominated occupations, the most interesting data come from a study by the Norwegian labor market researcher Helge Svare (2011). Svare has been associated with a pilot project on men in care work (Menn I Omsorgsyrker), which sought to investigate how to increase the recruitment of men into care occupations by focusing on a concrete case: a residential institution (Solkollen) which cared for the elderly. During the 2007-2008 project period, three men left their jobs at the facility, and they were asked about their motivations for resigning. The high pace of work, and the resulting feeling of not being able to do their jobs in a satisfactory way, was highlighted as the main factor behind their exit. Being overburdened, they felt they could no longer see any meaning in continuing their jobs. The men felt burnt-out to such a degree that it had a negative impact on their family and personal lives. Another factor highlighted by these men was the lack of positive feedback from the management of the facility. While they were sympathetic to the pressures on their supervisors, the lack of feedback still led to reduced job satisfaction and lack of motivation. Finally, the three men linked their work frustration to the municipal authority employing them and the structural and institutional conditions that led to inadequate budgets and the authorities' failure to take the needed measures.

In an older American study based on questionnaire data from 1981, this group of men is also represented, even though the study centers on men who are still employed in female-dominated occupations (Williams and Villemez 1993). The data from this statistical study indicate that men who exit from female-dominated jobs obtain an increased salary and greater job satisfaction. However, we are still left without any knowledge of why men chose to leave the female-dominated occupations in the first place.

A Danish study using register data identifies several personal and external factors associated with the exit of men from home care and institutional care jobs (Hjalager et al. 2004). One of the findings of this study is that the male personnel within these two areas constitute a less stable labor force than the female personnel, which indicates that the problem of retention has a gender dimension. The tendency is that the more experience men have as professional caregivers, the greater the probability that they will remain in the field. This has led the researchers to emphasize the challenge of holding onto men until they obtain the necessary experience. As a proposed explanation for why men leave work in home care and institutional care fields, the researchers cite factors such as the working environment, the content of the work, and the working conditions. 
Finally, three other Danish studies make peripheral mention of men who leave the caregiving sector. A register-based analysis of graduates (Jensen and Haselmann 2012) concludes that male students in strongly female-dominated educations, such as nursing or childcare, run a greater risk of withdrawing from studies than do women in these educational programs. In one study (Bloksgaard 2009) of two gender-dominated occupations-the female-dominated social and health workers and the male-dominated electrician branch-21 men and 19 women were interviewed. Among the 21 men working as social and health workers, two of them have chosen to leave that sector. Finally, a study by Ulla Wohlgemuth (2010) uses 35 interviews with men, four of whom are studying to be child/youth workers who have withdrawn from their studies. Neither of these two aforementioned interview-based studies offers any independent analyses or conclusions regarding the experiences of the men who have withdrawn from these fields.

\section{Men as gender minorities on the labor market}

Since there is a lack of studies on men who exit caring occupations, I will present a framework that builds on three theories focusing on tokenism, men as gender minorities, and hegemonic masculinities.

The American organizational researcher Rosabeth Moss Kanter (1977), in her classic studies of minorities, shows how minorities (tokens) in the form of female managers in a large corporation are very visible and therefore their performances and behavior are constantly assessed and judged by the majority group (men). As a consequence many tokens experience performance pressure. Many tokens try to blend in and become anonymous, and hereby reduce the unwanted attention. Also tokens are often viewed as contrasts and kept in the periphery of the social community. A third and final tendency, Kanter identifies, is that tokens are expected to behave in accordance with preexisting (often stereotypical) generalizations about them as a group; they are forced into assimilation and encounter a situation of role encapsulation. However, Kanter has been criticized for being too structural-determinist in her approach, and that her conclusions are gender-specific, that is, an expression of her empirical orientation in situations where women are minorities (cf. Bloksgaard and Faber 2004; Simpson 2004; Warming 2012; Williams 1995).

As a reaction of Kanter's neglect of the gender power hierarchy, and too strong emphasis on structures, Christine L. Williams (1995) develops a theory based on interview with men who work in four female-dominated occupations. The fundamental difference between Kanter's and Williams' findings is the presence of privileges. Williams conclude that male minorities do not experience social isolation, and the demand for assimilation is present only to a limited extent. However, they are expected to demonstrate traditional masculine characteristics, and to take care of (stereo-)typical male jobs. Many men meet what Williams labels the glass escalator, where men are easily promoted to management positions. Finally Williams identifies a number of social strategies men utilize in order to distance themselves from the traditional care worker (i.e., women) and hereby maintain hegemonic masculinity; specialization in certain (masculine) areas, highlight (masculine) features of their work, consider their current work as a springboard to a (masculine) future position, and distance themselves emotionally from their work.

In her understanding of masculinities Williams draws on Robert Connell's (1995) theory of the patriarchal dividend, where men are both different from and superior to 
women. However, Connell is criticized by Wetherell and Edley (1999) for not specifying what conformity with hegemonic masculinity looks like in practice. Therefore, they identify three imaginary masculine positions. Heroic, where men position themselves as courageous, physically tough, cool, and in control. Rebellious, which is a rejection of macho masculinity. Masculinity is perceived as being able to ignore social expectations and follow personal preferences. Also if these actions are regarded as unmanly or effeminate from a normative perspective. The final position is labeled ordinary. This is when men consider themselves normal, average, or moderate.

\section{Method}

This article is based on qualitative interviews with Danish men who discuss their motives for leaving the caring occupations (or in some cases dropped out of care-based educational programs). These men live in different parts of Denmark, where they have had experiences as professional caregivers in the social and health sector, nursing, and childcare/youth work. More specifically, they have worked as social and health care helpers for the elderly, hospital nurses, preschool day-care workers, pedagogue aides, or have dropped out of the training programs as social and health care helpers, or they intend to leave the field as soon as they have completed their training.

It has been a great challenge to come into contact with these 11 men. Through a Facebook group for male nurses (the Danish name is Mandlige sygeplejersker), 66 men were contacted, of whom 3 responded that they would participate. Seven other men were identified through a review of internal member lists in the employee trade union FOA-Trade and Labor, where 147 men who had recently left the union were contacted with a request to participate in the study. Finally, one man was interviewed in 2008 in connection with a study of men's motivations for choosing caregiving fields and their experiences as gender minorities in these female-dominated fields and this interview was reused. Five men were interviewed face-to-face (two in their private homes, two at my office, and one at his workplace), while the remaining six were interviewed by phone because of practical issues. All interviews were conducted by the author-10 during the spring of 2011 and the last one in 2008-and the fact that both the interviewer and interviewees are men could have had an effect on the men's responses (see Williams and Heikes 1993 for possible consequences).

The interviews, lasting from 45 to 75 minutes, were digitally recorded and transcribed in their full length for analysis. The interviews were conducted in Danish, and selected excerpts were translated into English for this article. A dynamic, semistructured guide with open-ended questions was used, so I would be able to follow up on interesting insights that came up during the interviews (Kvale and Brinkmann 2008). Since no other studies on men who exit caring occupation exist, this last, explorative dimension was important. The guide was constructed around a number of key themes: personal background, general work history, motivation to become a care worker, social reactions for choosing a gender nontraditional field of work, experiences being a male care worker, work tasks, discrimination (positive and negative), social work environment, and reasons for leaving the care sector. Not all themes are covered in this article, since the ambition is to explore why men stop caring and leave caring occupations. 
Three of the interviewed men were nurses and one a childcare worker (poedagog). All four have earned Bachelor's degrees in their fields. Among the five social and health workers, one has dropped out of school, two are still in school (but will leave after they complete their educations), one has no formal training, and the fifth interviewee has a lower-level vocational training of one year and seven months (social and health care helper). Finally, two interviewees have worked as untrained pedagogical assistants in child/youth institutions.

The procedure for analyzing the interviews was divided into three phases. First, each interview was analyzed in order to create an overview and generate introductory analytical categories and themes. The interviews were then analyzed within each of the three occupational fields. Finally meta-themes were generated across the three occupational areas. When analyzing the data, I moved back and forth between a descriptive-illustrative level and more analytical-reflexive level. Through the entire analytical process, I was careful to be faithful to the men's narratives, and at the same time maintain analytical distance.

It should be remarked that the data reflect differences in the men's expressed motivations for why they have chosen to exit the care sector. The goal of this analysis is not to discuss these differences as such, but to identify a broad range of factors that cause men to leave these occupations. In addition, it should be emphasized that while certain conditions are described as unsatisfactory to such a degree that some men leave their caregiving jobs, other men cite these same factors as positive, and as the reason why their exit is connected with a degree of regret or sadness.

Finally, it should be emphasized that the analysis builds on narratives from men who for one or another reason no longer desire to work in the care sector. This might explain why their accounts would be more negative than accounts given by men still working in caring occupations (e.g., Heppner and Heppner 2009; Simpson 2005).

I wish to underline that the following analysis does not represent the only possible and meaningful interpretation of the men's narratives. It should also be recalled that any interview is a collection of subjective statements, experiences, and descriptions rather than a description of what actually happened (Järvinen 2005; Kvale and Brinkmann 2008). The intention with this article is to produce a level of insight into an under-elucidated field of research by placing a relatively greater focus on situational descriptions, and thereby fulfill an exploratory objective (Kvale and Brinkmann 2008; Maaløe 1996) so that our knowledge of men in caring professions becomes deeper, more refined, and has a broader empirical foundation.

\section{Results of the interview study}

The following analyses focus on a broad spectrum of factors, all of which-to a greater or lesser degree or in different ways-contribute to men's decisions to leave care work.

\section{Assimilation: "This is not how we are used to doing this kind of thing around here"}

One of the factors that many men cite in explaining their exit is the social working environment, which in most cases consists exclusively of female colleagues and superiors. 
The men state that they encounter a form of interaction-in both action and speechthat is far from what they are accustomed to, be it from their experience from former jobs or in their personal lives.

Several of the men state that the way in which their work is supposed to be carried out is very traditional-bound and "female." When they express their alternative ideas or offer what they feel are better solutions, the men say that they are brushed aside by the women with remarks such as "Of course, men cannot figure out things like this" and "This is not how we are used to doing this kind of thing around here." The men interpreted this attitude as a lack of willingness on the part of their colleagues to enter into dialogue. It made them feel locked in, paralyzed, and in certain cases incompetent, just as their gender-linked difference is put on exhibit in the reactions they encounter. These feelings are reinforced by the fact that the men are often alone in challenging the norms and the established workplace culture, which they explain by saying that they do not have male colleagues who can back them up during a situation of controversy (see also Svare 2011). As a result, the men feel professionally and socially marginalized. "You work on the women's terms," as one of the men expressed it.

This study contradicts Williams as well as the criticism often expressed against Kanter, in that the men I interviewed have experienced many of the negative aspects of the minority position identified by Kanter and which other researchers relate to her interviewees' (female) gender.

Another explanation for the men's experience can be found in the study by the Italian sociologist of work Silva Gherardi (1995), who asserts that in single-gendered work groups there occurs a (stereotyped) "celebration of gender," whereby the gender minority individual is welcomed and protected as long as he/she has no authority. In this view, the men's attempts to challenge or cast doubt on established work routines causes the women's hostile, denigrating, or exclusionary reactions.

One example of the inertia in work routines is articulated by a man who after several years of employment in various caregiving institutions had decided to leave the care field completely. He explains:

'In my view [the male residents of the institution] were forced to take on some very female values or ways of acting. [...] So I felt that I had to fight for even very small things for the residents, which one could perhaps say were kind of man-like things. [...] If a resident wanted to grow a beard for some days, for example, it was a [...] battle I had to take on, and it could take hours. If a resident refused to eat salad and would rather have five meatballs and one potato instead of five potatoes and one meatball, well, the resident was not allowed. [...] As a man in that environment, I became entirely squeezed in.'

Statements like this reflect a general impression that a number of men in this study simply do not have the capacity or will to distinguish between what the women are responsible for and the structural conditions under which professional caregivers work. This poses the question of whether the men should sometimes be criticizing the system as such (including lack of resources, see below) rather than the attitude of their female colleagues.

One of the other men discusses an experience in caring for the elderly residents in a home for the aged. Here the care staff imposes several rules on the residents. In this man's view, the staff does not respect the residents' wishes, routines, and customary habits: 
'There are many people from the countryside here where I work, and they are not interested in having to put on clean clothes every day. Nor are they interested in having to be shaved every day. And many of them, they are in fact not interested in having to bathe every day, either. They have never been accustomed to this.'

In this professional discussion, several of the men have the view that the less interference in the individual's daily life, the better. Their attitude is that "basically, people can take care of themselves." The men find the unnecessary interference, including the "taking over" and "manipulation," as they call it, destructive for both the effectiveness of the care and the individual's autonomy. While the men feel that this struggle is lost in advance because of ingrained habits, traditions, and cultural stubbornness, a former nurse also feels that the women assessed his abilities as professional on the basis of some fundamentally incorrect and nonprofessional criteria: "If [the patients] have clean clothes on, then I am a good nurse. If they are soiled, then it's because I am a bad nurse." Svare (2011) calls this type of surveillance "the female pointed finger," a feature he also observes among female care workers working at the Norwegian Solkollen facility. He finds that these practices contribute to friction among colleagues, in that the women, on their own initiative and without any further discussion, take on-or are inserted intothis surveillance position.

The men provide numerous examples of situations where they were asked to perform tasks in a manner for which they could see no practical purpose, and where the women could not provide objective reasons for the men to do so. This caused some of the men to accuse several of their former colleagues of being ignorant and acting uncritically. For example, a former nurse explains how on several occasions, he inquired why the work procedures should always be carried out in a specific fixed sequence: "When I addressed myself to them and asked why it was this way, they did not have the slightest idea about it."

Several men express the view that they do not have the desire to continue to fight this struggle against the women: "It gets discouraging. It becomes a hard mental working environment." The men give up, leaving care work to seek careers elsewhere. Not all the men feel discouraged, however. Several of the men feel that in spite of only a few years (or less) of working experience and thereby limited professional qualifications, they have the legitimacy to pose questions about the work procedures.

All the interviewees expressed the view that the caring occupations lose a lot by not being amenable to change and by not being able to incorporate suggestions presented by the sector's few male employees. Similarly, the culture is viewed as one that pushes men away. Related to Margaret Wetherell and Nigel Edley's (1999) understanding of masculinity then this demand for assimilation prevents men from being in control and practicing traditional/patriarchal masculinity.

\section{Hierarchy: "We have never met a real man out here, goddammit"}

Several men provide examples of their encounter with female colleagues who treat them in a manner which they find degrading, exclusionary, or disqualifying.

'It's what's called "bullying". They sit there, for example, these women, and say, "We have never met a real man out here, goddammit", and "We don't know what the hell kind of 
weaklings start working here". And on the first day we were also told that they we should get coffee for them. I took it as a joke. I sat and laughed, but I quickly realized that they meant it, goddammit.'

Following Connell (cf. above), men, due to their gender, have a symbolic power over women which can be traced back to patriarchal thinking, to which both women and men have been subordinated. As such, power becomes a fundamental expression of masculinity (Kimmel 1994). Several of the interviewed men experienced ruptures in this power relationship, in that they were denied this position. Their female colleagues did not consider them to be "real" men (see also Gherardi 1995; Holter 2003; Williams 1993), and they were forced into the inferior power position symbolically associated with women. In other words, the gender power order seems to be reversed, with the woman as the dominant/superior party and the men as subordinate, as illustrated by the men's experience of feeling emasculated and de-masculinized.

One possible interpretation of the women's behavior can be connected to the tokenism mechanisms which in this case emerge when a man moves into a caring occupation-into the women's domain. The man is considered as being representative of his gender (Kanter 1977). This creates an arena where the women, due to their numerical superiority and the specific culture of the workplace, are able to rebel against the traditional power hierarchy. Or it could be that the women desire homosociality and therefore are uncomfortable with an "outsider" that challenges sameness.

An alternative to the men's description is the interpretation that this "devaluation" is not due to gender-related factors but rather to the existence of an informal senioritybased hierarchy in the workplace, where those who are not yet trained-i.e., the apprentices, interns, and relative newcomers-occupy the lowest rank in the hierarchy regardless of gender. This interpretation is confirmed by the fact that the men in this study have worked in the care sector an average of four years, but that several of their experiences are also based on their time as trainees, that is, experiences they had while still students. Hence, their colleagues' expectations that the men should "get coffee for them" and the bullying behavior could have their origin in the men having relatively limited experience, and thereby low professional status. In addition, it should be recalled that these female-dominated workplace cultures often have no or very limited experience with male caregivers, so that an institutionalized gender hierarchy is nonexistent. Hence, a plausible explanation of the situation can be that the men's inferior positions, and thereby inability to take on the traditional male power position, is grounded in occupational hierarchies of seniors and juniors, and not (necessarily) in what some of the men interpreted as a gender-based subordination of them as men.

\section{Social exclusion: "It's not your concern"}

The atmosphere in the workplace and the way in which the female colleagues address each other and the men, and the patients, children, and elderly residents, is presented as a relationship that several men find difficult to deal with. In terms of collegial interaction, especially during the work breaks, several men experience being excluded from or denied access to the group, which contradicts existing research on men in femaledominated occupations (e.g., Bloksgaard and Faber 2004; Simpson 2004, 2005; Sjørup 
2005; Warming 2012; Williams 1995). They describe a form of interaction that is very strange to them, almost unapproachable, and they find it difficult to become part of or even decode the conversations. For example:

'When I either pop in or walk by our lounge room, where the staff members are sitting, they sit $[\ldots]$ and whisper to each other. [...] For example, you sit in pairs and say something which others must not hear. If you ask them about it, you are told that it's not your concern. [...] They have some ways of making intrigues that we men just can't understand, you know. [...] It's things like this that make it so incredibly tiring to be there.'

As reaction to this exclusion from the community of work colleagues, many of the men resign themselves to the situation. They take a break by themselves or attempt to get together with other men at the workplace in order to establish a homosocial community where they can, among other things, discuss common interests as well as the special conditions that apply to male care workers (Bird 1996, see also Bloksgaard 2010; Kimmel 1994; Svare 2011; Warming 2005; Williams 1995). Yet it is often the case that there is no possibility to do this, as the number of men working in female-dominated workplaces is small, and the few men who are employed are seldom at work all at the same time, much less take a pause at the same time. In certain cases, the possibility exists for male sociality, but this is not synonymous with the men actually seeking this out. Hence, one of the men points out that he does not desire to spend his time with, much less identify with, his male colleagues, because he sees their behavior as "unmanly": "But now you really have to make sure that you call a man 'a man' around here [in the home care workplace] [...] For I have seen the men who are here. And you know-sorry to say this-some of them are real 'pussies' [the Danish term is kollinger]."

In several cases, the workplace environment (see also Hjalager et al. 2004) and thereby the relations with their female colleagues have been instrumental in causing the men to decide to leave the care sector and return to traditional male occupations where they had formerly worked (e.g., armed forces, butcher, landscaping), to change careers (see below), to go on to higher education (e.g., at universities), or to become unemployed, a situation that a few interviewees preferred over continued employment in a caring occupation.

\section{Resources: "You just don't have the time and the means to do it"}

An oft-stated motivation for the interviewed men in choosing to leave the caring occupations is that they felt pressured between providing the necessary care which the clients, children, and elderly needed versus having to observe the ever stricter time restrictions on their work process. Several interviewees expressed frustration about not being to provide a level of health care, assistance, or pedagogical care that they knew would give results (see also FOA 2009). One man who at the time of the interview was "changing horses" after 12 years as a childcare worker gives the following explanation for his exit:

'I have some high ideals about what reality should look like, and how everyday life should be for the people I take care of and with whom I am dealing. And the ideals, they are always far, far higher than what the realities are. [...] And then the work begins to become 
less meaningful $[\ldots]$ because theoretically you certainly often know very well what would be good and healthy and sensible to do for the person, but you just don't have the time and the means to do it. [...] And in reality, I am really wildly happy about being a childcare worker and would really prefer to continue with it. [...] If the working conditions were much better, I would also [...] feel better when I came home from work.'

The interview data provide innumerable examples of work norms that have become more stringent and working procedures that have become more rigid. The result is that the possibilities to "give that extra" and to fix "the small things which mean a lot in everyday life" disappear. An argument given by several of the interviewed men for choosing to work in the care sector is precisely this possibility to make a difference (see also Bloksgaard 2009; Svare 2011; Warming 2011). These arguments are most likely not gender specific, but common for workers in the care sector. As the work pace increases, so do the feelings of frustration and burnout, all of which affect the worker's job satisfaction and ultimately, their life quality. A former caregiver describes the kinds of tensions which several of the men have experienced, saying that during the time just before he quit his job in home care, he was "a bad employee for the municipality, but I felt I was a good caregiver." In other words, he prioritized the human care at the cost of rules and procedures.

\section{Wage conditions: "A written insult each month”}

While the men uniformly emphasize that they did not seek employment in the care sector because of advantageous wage conditions, several of the men point out that the compensation has nevertheless had an effect on their decision to leave the sector. One of the men felt himself forced to leave pedagogical work for university training and a subsequently better paid job, in that his future plans would not be realizable without a higher salary level.

'My biggest problem has always been the salary. Had the salary been better, then I think perhaps, that this would have been my permanent occupation instead of being an engineer [...] I do not think that I can support a family with what you earn as a childcare worker. [...] [Childcare work] has always been what I think has been really interesting and fun [...], and if my world could be perfect, then it would be that I could work as a childcare worker and then have some kind of extra job, where I went around to people and fixed their computers just for fun and then messed around a bit, because I think it's fun.'

Along with this, another younger man articulates the practical dimension of the wage conditions in home care as an economic barrier preventing him and his partner from establishing themselves as a family with home and children. Among several of the men interviewed, there seems to be a predominant understanding of the man as the one who supports the family, even though they have spouses with jobs, or cohabiting girlfriends who contribute to the household economy. The same situation is also found by the Norwegian masculinity researcher Øystein Holter (2003), who points out that even though most modern households are based on two incomes, the image of the man as provider still predominates. Similarly, the British masculinity researcher David Morgan (1992), 
discussing several sociological studies, concludes that the linkage between the provider role and masculinity is fundamental to the man's self-understanding (see also Reinicke 2011).

One of the men exhibits what could be called a traditional wage-labor perspective; he strongly considers "finding a purely wage-slave job simply in order to earn money," now that he has left his occupation as childcare worker. Similarly, a former nurse states that the "pay check is practically a written insult each month." Although the men were familiar with the well-documented pay gap in the care sector prior to having chosen this field (e.g., Albæk and Thomsen 2011; Lønkommissionen 2010), and though they expressed this awareness with statements such as "this will never become something that I will become so immensely wealthy from," they were nevertheless surprised about what they view as a low wage level.

The men who are in their new, "masculine" jobs state that their wages have increased (see also Williams and Villemez 1993). A former nurse who is now an officer in the Danish home guard explains that for him, the change meant "10,000 DKK [per month] more for the same hours," while another man who had formerly worked in elder care, but is now a baker's apprentice, points out that "I get 128 [DKK/hour] now, and this is an unskilled worker's wage, and already more than what I received as a social and healthcare worker." Yet another study (Bloksgaard 2009) also shows that low wages discourage the men from remaining in the care sector, but that the low wages are normally (cf., paragraph on lack of resources above) compensated by the greater degree of job satisfaction. The prospect of both higher wages and greater job satisfaction in a traditional male-dominated occupation (see also Albæk and Thomsen 2011) has led several of the men to leave the care occupations.

\section{Other factors: Smells, accusations, and springboards}

Several other work-related factors are highlighted as negative, even though they have not been cited as direct causes for the men's decision to leave the care sector. For example, some of the men who had worked with home care or nursing emphasize especially unpleasant tasks such as "washing people's behinds" as something they would prefer to do without. One of the men states that "it will never ever be something I would come to like very much .... to go and smell other people's excrement. [...] It is something I can stand for a while." Another interviewee states that he "nearly vomited each time," while a third, with a twinkle in his eye and ironic distance, characterizes his previous job as "professional ass-wiper" (see also Isaksen 2002). Tasks such as these are also described as the basis for the ridicule and puzzlement that the men encountered when they described their caregiving work to others. Even though the practical work with cleaning of bodies constituted a relatively small part of their working day in terms of time spent, such intimate body tasks have great importance for the men's understanding of care work.

Changing diapers of infants—and being physical with children in general-also constituted a problem for the men who worked with children within the pedagogical field. The explanation here, however, is not unpleasantness with the task itself, but rather the fear that in carrying out these tasks, they might be suspected of pedophilia. In order to avoid situations which might be misinterpreted and create the basis for pedophilia accusations, the men trained themselves in several institutionalized work routines which 
ensured that episodes that could be misinterpreted did not occur (see also Warming $2005,2011)$. For example, several of the men explain that they neither changed children's diapers nor took them on excursions outside the day-care center without another adult being present, just as they never permitted children to sit on their laps.

'It is among the worst things that can happen to you-a pedophile accusation. [...] I can well understand that it [...] is part of this total assessment of: "Hey, do you want to be in such a place [read: work with small children], or do you not want to be in such a place?".'

Finally, a few of the men who were interviewed expressed, in accordance with Williams (1995), an ambition to use their educations and/or experiences in the care sector as a point of departure for a career within a new field or at another level. Hence, one man who had been unemployed for a longer period of time stated that his plan was to use his training as social and health care helper "as a springboard so that I can get back onto the path that I want to," while another points out that the unskilled job in home care was a "step on my stairway that I am climbing." One man chose nursing because it was "the field which reminded me most of medicine." His intention was to earn university "points," so that he could more easily gain admission to medical school and thereby get "into something which I could better identity myself with," drawing on the familiar image of men as physicians and women as nurses (see also Sjørup 2005).

\section{Conclusions and suggestions on how to retain men}

The results of this study point to several factors affecting the retention of men in the care sector. Some of these factors are linked to specific work routines, while others reflect the importance of the social working environment for causing men to leave the sector. Where the social environment is a factor, a solution lies in change of attitude and greater cultural openness by the women working in the care sector.

Time and personnel pressures and inadequate framework conditions for carrying out care are factors which nearly all the interviewed men emphasized as major causes behind their change of career. The men simply become disillusioned and frustrated. With more tasks and growing requirements for control and registration of work procedures, the men feel unable to provide adequate care to their clients. The men take these feelings home with them at the end of their work day, becoming burnt-out or even ill, so that their only way out of the dilemma is to move into another field. This is despite the fact that several of them would really prefer to remain care workers. It is a downward spiral, in that fewer people to carry out these tasks means that the remaining workers are under even more pressure, with the consequent risk of further burnout and illness, exit, etc.

The effort will not be adequate, however, if the problem is viewed only as low salaries or insufficient staff. Beyond the lack of resources in the care sector, the men underscore that the negative social working environment of the female-dominated workplaces has greatly affected their decisions to leave care work. The men encounter a workplace culture which is pervaded by traditions and habits that discourage them from discussing alternative models for how work should be carried out or problems solved, just 
as several men report encountering a lack of confidence by their female colleagues in their professional skills as male care workers. The fact that they have chosen a femaledominated occupation leads to their being denigrated by their female colleagues as not "real" men.

In relation to the work collective at the women's workplace, the men feel excluded: they are told that they should not interfere, or the women whisper among themselves so that the men find it impossible to participate in the conversation. The men become resigned to the situation. In most cases, they do not have male colleagues with whom they can interact, so they end up being socially isolated. The social belonging that could function as a shield against burnout and as a safety valve for frustrations is lacking. The result is that men feel pushed away from care work, just as several men do not have any identification with their female colleagues (and in certain cases nor with their male ones, if they have any). A larger degree of cultural receptivity, less inertia, and more male colleagues would, according to the men, help to prevent the relatively large dropout rate of men.

The low appreciation of care workers, as reflected in low wages, is also emphasized as problematic, and a few men indicate low wages as a contributing factor for why they have left the care sector. The wage level has both a practical dimension, in that younger men indicate that their family dreams cannot be realized, and a value dimension, where the men feel that their wages are not commensurate with their skills, their responsibilities, and with the essential social tasks they carry out. Yet the majority of the men say that higher wages alone cannot get them to return to care work. In their view, the lack of resources and the social working environment constitute a greater obstacle to job satisfaction and personal well-being.

An important conclusion which can be derived from most of the men's accounts is that their exit from care work is not due to the content of the work itself, nor to the fact that the female-dominated care work is traditionally considered "unmanly." The men place high value on care of children, care of the sick, and care of the elderly. Rather, their dissatisfaction is with external conditions. The men's valuation of care work as such is a fundamentally positive condition. If more men are to be retained in the care work sector, then it is working conditions and the social working environment that need to be changed. However, this can only be accomplished if there is political will, management commitment, and collegial inclination to do so.

The great satisfaction that most of the men felt working in the care sector manifests itself among those who have left care work. Several of them experienced a feeling of loss in not being able to work as caregivers. As one ex-caregiver lamented: "I can also feel a little lump in my throat while I'm talking about it here. It was-you might say-like someone who dreams of becoming a pilot, so I think it was my pilot dream.”

\section{References}

Albæk, K. and Thomsen, L. B. (2011) Er kvindefag lavtlønsfag? [Are women's occupations low paid?]. Copenhagen: The Danish National Centre for Social Research.

Bird, S. (1996) 'Welcome to the men's club: homosociality and the maintenance of hegemonic masculinity', Gender and Society 10(2): 120-132.

Bloksgaard, L. (2009) 'Mænd i SOSU-faget og kvinder i elfaget' [Men as social and health care workers and women as electricians], LO-Dokumentation 2: 58-94. 
Bloksgaard, L. (2010) 'Maskuliniteter, femininiteter og arbejde' [Masculinities, femininities and work], Tidsskrift for Arbejdsliv [Danish Journal for Working Life] 13(2): 19-35.

Bloksgaard, L. and Faber, S. (2004) Køn på arbejde [Gender at work]. Aalborg: Aalborg University Press.

Connell, R. (1995) Masculinities. Cambridge: Polity Press.

Department for Gender Equality (2011) Perspective and Action plan 2011. Copenhagen: Department for Gender Equality.

European Institute for Gender Equality (2013) Gender Equality Index Report. Vilnius: European Institute for Gender Equality.

FOA (2009) Det siger FOAs medlemmer $i$ dagtilbud om besparelser [FOA members in daycare on savings]. October 29, 2009. Retrieved from http://www.foa.dk/Forbund/ Presse/Rapporter-undersoegelser/Medlemmer/2009/ /media/Faelles/PDF/Rapporterundersoegelser/2009/Medlemspuls\%20brneomrdet\%20oktober\%202009pdf.ashx

Gherardi, S. (1995) Køn-noget vi tænker, noget vi gør i vores daglige liv i organisationer [The gender we think, the gender we do in our everyday organizational lives]. In FlenstedJensen, E.; Højgaard, L.; Markussen, R.; Sjørup, K. and Sørensen A. S. (eds): Køn og kultur $i$ organisationer [Gender and culture in organizations]. Odense: Odense Universitetsforlag, pp. 11-38.

Heppner, M. and Heppner, P. (2009) 'On men and work. Taking the road less travelled', Journal of Career Development 1: 49-67.

Hjalager, A. M.; Sørensen, J. H. and Møberg, R. J. (2004) Florence Nightingale på tilbagetog? [Florence Nightingale in retreat?]. Aalborg: AMU Nordjylland.

Holt, H.; Geerdsen, L. P.; Christensen, G.; Klitgaard, C. and Lind, M. L. (2006) Det kønsopdelte arbejdsmarked [The gender-segregated labor market]. Copenhagen: The Danish National Centre for Social Research.

Holter, Ø. G. (2003) Can men do it? Copenhagen: Nordic Council of Ministers.

Isaksen, L. W. (2002) 'Masculine dignity and the dirty body', NORA-Nordic Journal of Women's Studies 10(3): 137-146.

Jensen, T. P. and Haselmann, S. (2012) Tilgang til professionsbacheloruddannelserne og de nyuddannedes beskeftigelse [Professional Bachelor Programme uptake and employment of new graduates]. Copenhagen: Forlaget AKF.

Järvinen, M. (2005) Interview i en interaktionistisk begrebsramme [Interview in an interactionistic conceptual framework]. In Järvinen, M. and Mik-Meyer, N. (eds): Kvalitative metoder $i$ et interaktionistisk perspektiv [Qualitative methods in an interactionistic perspective]. Copenhagen: Hans Reitzels Forlag, 27-48.

Kanter, R. M. (1977) Men and women of the corporation. New York: Basic Books.

Kimmel, M. (1994) Masculinity as homophobia. In Brod, H. and Kaufman, M. (eds): Theorizing masculinities. USA: SAGE Publications, 119-141.

Kudahl, S. (2009) 'Mangel på kommunale hænder truer velfærden' [Shortage of public employees threaten our welfare], Momentum 5(1): 1-4.

Kvale, S. and Brinkmann, S. (2008) InterView. London: SAGE Publications.

Liversage, A. (2009) 'Kvinder i malerfaget' [Women in the housepainting trade], LO-Dokumentation 2: 16-57.

Lønkommissionen (2010). Løn, køn, uddannelse og fleksibilitet. Bind I. [Wage, gender, education and flexibility. Volume I]. August 17, 2011. Retrieved from http://www.lonkommissionen.dk/pdf/Bind_1.pdf

Maaløe, E. (1996) Case-studier af og om mennesker i organisationer [Case studies of and on people in organizations]. Copenhagen: Akademisk forlag.

Morgan, D. (1992) Discovering men. London: Routledge.

Nielsen, S. B. (ed) (2011) Nordiske mand til omsorgsarbejde! [Nordic men to care work!]. Roskilde: VELPRO. 
Reinicke, K. (2011) Maskulinitet, mandeforskning og ligestilling [Masculinity, men's studies and equality]. In Greve, B. (ed): Grundbog i Socialvidenskab [Introduction to social science]. Frederiksberg: Nyt fra Samfundsvidenskaberne, pp. 204-221.

Simpson, R. (2004) 'Masculinity at work', Work, Employment and Society 18(2): 349-368.

Simpson, R. (2005) 'Men in non-traditional occupations', Gender, Work and Organisation 12(4): 363-380.

Sjørup, K. (ed) (2005) European men working in women's professions. Roskilde: The Danish Research Centre on Gender Equality.

Sjørup, K. (2011) Køn som forskelsmarkør på arbejdsmarkedet [Gender as a marker of differences in the labor market]. In Greve, B. (ed): Grundbog i Socialvidenskab [Introduction to social science]. Frederiksberg: Nyt fra Samfundsvidenskaberne, pp. 237-255.

Statistics Denmark (2013) Fald i ledighed i maj [Drop in unemployment rate in May). Copenhagen: Statistics Denmark, no. 350.

Svare, H. (2011) Om rekruttering af 'menn i omsorgsyrker' [On recruitment of 'men in caring occupations']. In Nielsen, S. B. (ed): Nordiske moend til omsorgsarbejde! [Nordic men to care work]. Roskilde: VELPRO, pp. 152-187.

Uni C (2012) Statistiske udtrcek fra Undervisningsministeriets databank [Statistics from the Ministry of Children and Education]. June 5, 2011. Retrieved from http://statweb.uni-c.dk/Databanken/uvmdataweb/fullClient/Default.aspx? report=EAK-tilgangerhudd\&res $=1540 \times 670$

Warming, K. (2005) Men working in women's professions. Roskilde: Danish Research Centre on Gender Equality.

Warming, K. (2011) 'Jeg vil lave noget, hvor jeg kan finde en livsglæde og føle, at jeg gør en forskel' [A job that feels good: men's motivations for entering caring occupations], Tidsskrift for Arbejdsliv 13(2): 42-58.

Warming, K. (2012) For better or for worse: experiences of men in caring occupations. In Schnarrs, P. W. and Maurino, J. P. (eds): Men, masculinity and the common good in an era of economic uncertainty. Tennessee: Men's Studies Press, 48-69.

Wetherell, M. and Edley, N. (1999) 'Negotiating hegemonic masculinity', Feminism \& Psychology 8(3): 335-356.

Williams, C. (1995) Still a man's world —men who do "women's work«. California: University of California Press.

Williams, C. and Heikes, E. (1993) 'The Importance of Researcher's Gender in the In-Depth Interview: Evidence from Two Case Studies of Male Nurses', Gender \& Society 7(2): 280-291.

Williams, S. and Villemez, W. (1993) Seekers and finders. In Williams, C. (ed): Doing "women's work". London: SAGE Publications, pp. 64-90.

Wohlgemuth, U. (2010) Moend og omsorg, hvorfor (ikke)? [Men and caring, why (not)?] Odense: University of Southern Denmark.

\section{End notes}

${ }^{1}$ This interest is expressed in policy initiatives and plans of action (e.g., Department for Gender Equality 2011), various projects (e.g., Flere moend. Tak! [More men. Please!]; MPower; SOS-mx; When This is a Man) and in various research studies and reports (e.g., Nielsen 2011; Wohlgemuth 2010; Bloksgaard 2009).

${ }^{2}$ The three programs shown in Table 1 include periods of classroom training alternating with periods of internship (the Danish term is praktik), so that the students obtain practical knowledge of what it is to work as caregiver while they are still in school. 